Available online at https:/ /jurnal.iainponorogo.ac.id/index.php/eltall

\title{
THE USE OF ICT IN ENGLISH TEACHING AT SMK (VOCATIONAL HIGH SCHOOL) REGENCY OF NGAWI DURING COVID-19 PANDEMIC
}

\author{
Ari Amnan \\ Muhammadiyah University of Surakarta \\ arirocker28@gmail.com
}

Abstracts

The objective of this research is to find out the English teaching during covid-19 pandemic. Due to the COVID-19 outbreak, all institutions of education in Indonesia held the teaching and learning from home as a way to reduce the outbreak the virus spread. The ministry of education has a partnership with some providers (online class) where teachers and students can utilize it as media freely, on the other hand, Teachers preferred to employ WhatsApp (WA) in conducting the class. Not all students have enough access to gain the facilities, such as the cost for buying internet data, mobile phone, and the reachable and stable signal for internet. Teachers and students may require eligible infrastructures to run the class properly.

Keywords: ICT., ELT., COVID-19.

\section{INTRODUCTION}

In the early year 2020, the world was shocked by the outbreak of a new virus. That virus is originally from Wuhan, China. Found in the late of December 2019. World Health Organization (WHO) names the virus severe acute respiratory syndrome coronavirus-2 (SARS-CoV-2) and the disease as Coronavius disease 2019 (COVID19). It is confirmed that the pneumonia transmission of COVID-19 can infect human to human rapidly (Yuliana, 2020:1)

Nowadays, most governments around the world have for the moment closed educational institutions in an effort to stop the spread of the COVID-19 pandemic. It is also implemented in Indonesia, all institutions of education are closed and asked to conduct the teaching and learning from home. Based on the letter of Minister of education (Chabibie, 2020), especially for area which is impacted by Covid-19, should obey as the following instruction ; The process of Learning must be run toward online, Teachers do the activities from home through video conference, digital documents, and another online source to set the class.

Beside the ministry of education and culture has employed the online platform to set the class, the creativities of teachers are really needed in this pandemic. Teachers are required to master Information and Communication Technology (ICT), and to keep the students learning process at home. There are some challenges in conducting online class for teachers such as; the teacher competence of using learning-apps, the internet service which not all area can 
reach, and the communication among teachers-students-parent that is not integrated.

The term used by teachers in doing works at home is called by "work from home" (WFH). Because of prevention of the COVID-19 outbreak, and to take down the chain of virus spreading, teachers and students might do the learning process from home trough online service.

This research is about to find out the teachers way in delivering class (teaching) which belongs to ICT where teacher must employ technology in conducting the activities of home schooling.

\section{Underlying theories}

According to Craig R. Barret cited in (Ammanni, 2016:1), Technology enable teachers to become leaders in the education transformation around the world. Technology which was created by human is able to make easier the learning process. 21st century era gets citizens to utilize of technology in daily activities; one of them is in education. In this field, the mixing of technology in the classroom is out looked as an central approach to raise the effectiveness of the teaching and learning process ( Budiman, 2018:2).

The phrase "information and communication technologies" (ICT) refers to forms of technology which are used for broadcasting processing, storing, creating, displaying, sharing or exchanging information by electronic means. The broad definition of ICT includes such as technologies as radio, television, video, DVD, telephone (both fixed line and mobile phones), satellite systems, and computer and network hardware and software, as well as the equipment and services associated with these technologies, such as video conferencing, email and blogs (Alkamel \& Chouthaiwale, 2019). Then, Asabere and Enguah in (Cakiki, 2016) defined ICT as the utensils, services, processes, and gears that supply the required environment with the physical infrastructure and the services for the generation, transmission, processing, storing and disseminating of information in all forms including voice, text, data, graphics and video.

Furhermore, Based on UNDP cited in (Cakiki, 2016:3) ICTs may be defined as information-handling devices- a varied set of stuffs, applications and services which are employed for producing, storing, processing, distributing and exchanging information. They include the 'old' ICTs of radio, television and telephone, and the 'new' ICTs of computers, satellite and wireless technology and the Internet.

ICT allows course administrators and teachers to vary lesson presentation styles to motivate students of varying interests, provides learning opportunities outside the classroom, and is perceived to cater more for individual differences. Integrating technology into language instruction reduces teacher-centred understanding and students' language learning anxiety, but encourages them to be risk takers to practice target language as they are digital natives (Cakiki, 2016). 
Available online at https:/ /jurnal.iainponorogo.ac.id/index.php/eltall

\section{Research method}

This research belongs to qualitative research, which is according to Sharan B. and Merriam cited in (Sugiyono, 2017) as an inquiry approach useful for exploring and understanding a central phenomenon. The data were collected through questionnaires which spread toward Google-form to the community of English teacher of vocational high school organization called MGMP (Musyawarah Guru Mata Pelajaran) in Recency of Ngawi

\section{FINDING AND DISCUSSION}

Based on the letter of instruction issued by the Minister of education, especially for red zone (impacted by covid-19) the learning process should be held from home, As the information, several online course providers have made a partnership with the ministry of education and culture of Indonesia to provide free online class as the following table;

Table 1: Online class Partner

\begin{tabular}{|c|l|l|}
\hline No. & \multicolumn{1}{|c|}{$\begin{array}{l}\text { Online Class } \\
\text { Provider }\end{array}$} & \multicolumn{1}{c|}{ Page Address } \\
\hline 1. & Rumah Belajar & https://belajar.kemendikbud.go.id \\
\hline 2. & $\begin{array}{l}\text { Google G } \\
\text { Suites for } \\
\text { Education }\end{array}$ & $\begin{array}{l}\text { https://blog.google/outrearch- } \\
\text { initiatives/education/offline-access-covid19/ }\end{array}$ \\
\hline 3. & Kelas Pintar & https://kelaspintar.id \\
\hline 4. & $\begin{array}{l}\text { Microsoft } \\
\text { Office 365 }\end{array}$ & $\begin{array}{l}\text { https://microsoft.com/id- } \\
\text { id/education/products/office }\end{array}$ \\
\hline 5. & Quipper School & https://quipper.com/id/school/teachers \\
\hline 6. & $\begin{array}{l}\text { Sekolah Online } \\
\text { Ruang Guru }\end{array}$ & https:ruangguru.onelink.me/blPk/efe72b2e \\
\hline 7. & Sekolahmu & https://www.sekolah.mu/tanpabatas \\
\hline 8. & Zenius & https://zenius.net/belajar-mandiri \\
\hline
\end{tabular}


Available online at https:/ /jurnal.iainponorogo.ac.id/index.php/eltall

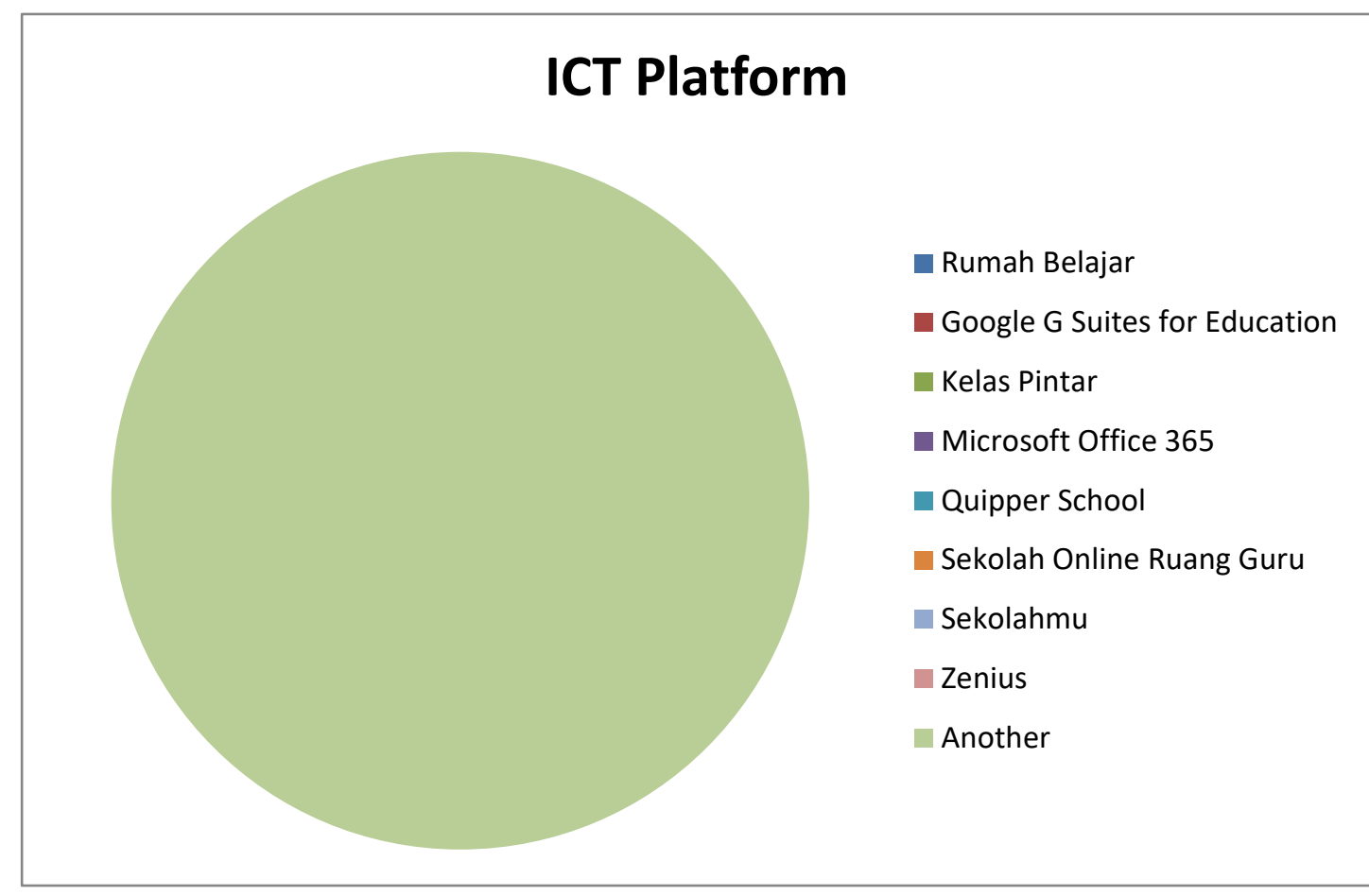

The data showed that no one of the teachers employed the online class that recommended by the minister of education and culture.

Chart 1.0: Teachers preference in online teaching

The English teachers of Vocational high school (SMK) of Ngawi mostly employed another choices; WhatsApp (WA) in conducting the class during pandemic.

In conducting the English class, teachers created WhatsApp Group (WAG) for each class which has functions as follow; 1). Teachers could communicate to students or vice versa, 2). Teachers could share some announcements, 3). Teachers could assign students to do some exercises, and then students submit the written one into JPG Format 4). Teachers could ask students to read materials then make the resume to be submitted to WAG, 5). Teachers could explain the materials in brief before giving exercise through WAG.

Not all students have good understanding to operate the office tools on Smartphone, so commonly; they do manually by writing on their own book note then take its photo to be submitted. During the class, Students faced some struggles. They had a problem when their internet data is empty. Without internet data, they couldn't join the class because they cannot access the WAG which required internet connection. Another struggle is the stability of internet connection. Students especially who stayed in the area that is difficult to find the service of internet, will get hard to join the class through WAG. 
Available online at https://jurnal.iainponorogo.ac.id/index.php/eltall

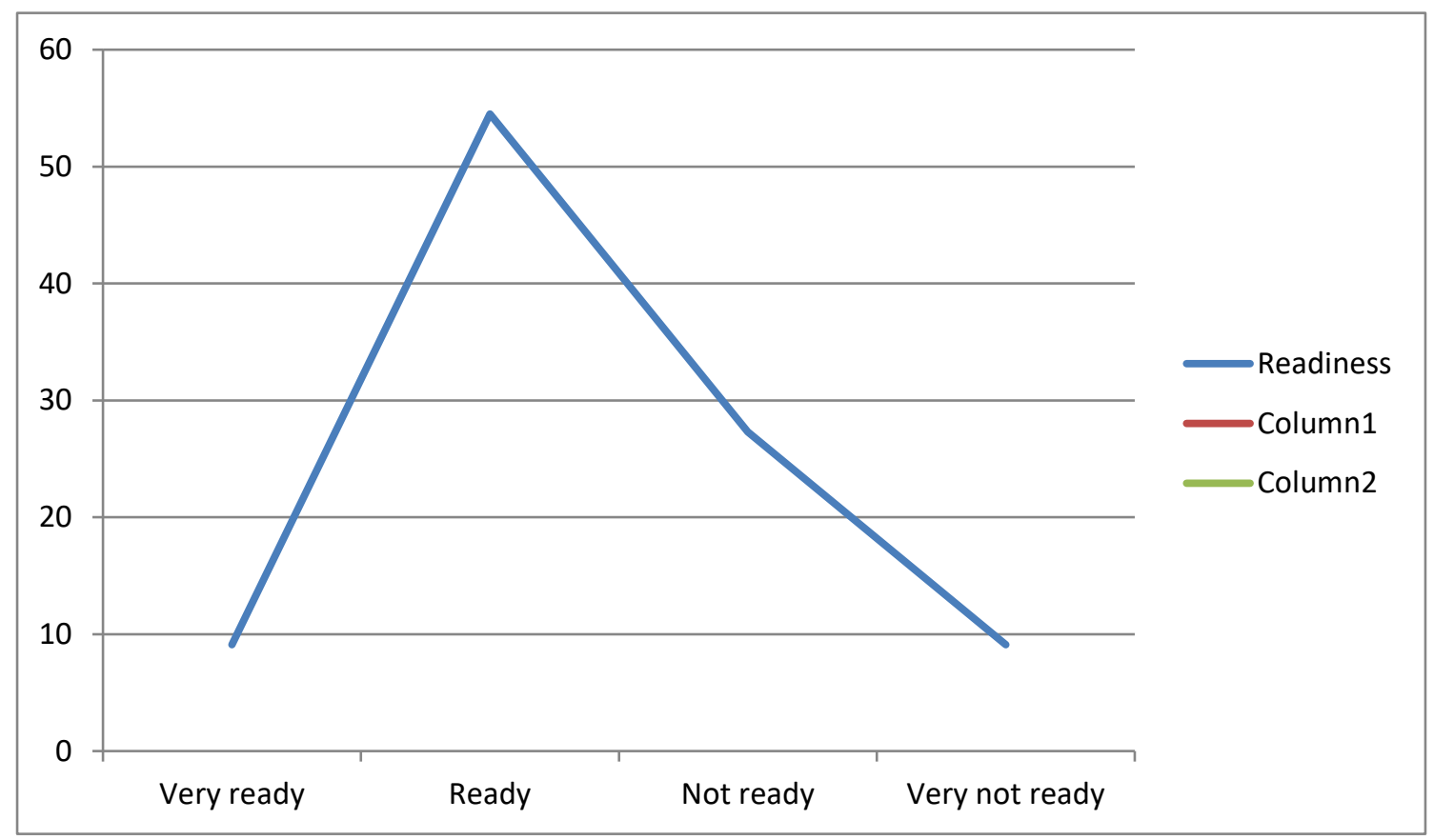

Chart 2.0: Teachers readiness

The data showed that teachers are ready enough in teaching English through online during pandemic although get some struggles.

Whereas teachers are steady, not all teachers have good knowledge in using online platform. It can be shown by their preferences. They preferred to employ WA to have the English class even though there are many options which are provided by governments above. They need to have a preliminary or introductory of teaching in pandemic. It means that teachers may have a bit description of what should they do during pandemic. They just get the instructions to teach online without clear description to be applied.

\section{CONCLUSIONS}

During pandemic, teachers keep teaching and do their obligation as educator through online class. Although the government has served some free online class, Teachers preferred to employ WhatsApp (WA) as the main tool for teachers in ruling the online class. Even though WA is able to conduct the class, it has a bit weakness; 1) not all students have mobile phone, it was in line with (Downes, 2020) Many learners might not have a mobile phone of their own and so yteachers will be sending messages to students via their parents phone. 2) Students' limits data, it was in line with (Downes, 2020) Some people won't 


\section{BL'TALL (RNGISSH IANGUAGE' 'TEACHING, APPIIEI) LINGUIS'IICS}

ANI) II'IIRA'TURI)

Vol. 1 No. 2, 2020

Available online at https:/ / jurnal.iainponorogo.ac.id/index.php/eltall

have a lot of data available for the lesson content. It should be considered about the content sharing use only text or small files.

Teachers and students may require eligible infrastructures to run the class properly. Because of the different capability, Students cannot be pushed to join the class through online class during pandemic.

\section{REFERENCES |}

Alkamel, M. A. A., \& Chouthaiwale, S. S. (2019). The Use of ICT Tools in English Language Teaching and Learning : A Literature THE USE OF ICT TOOLS IN ENGLISH LANGUAGE TEACHING AND LEARNING: A LITERATURE REVIEW. Journal of English Language And Literature (JOELL), (February).

Ammanni, S. (2016). The Role of ICT in English Language Teaching and Learning. International Journal of Scientific \& Engineering Research, $7(7), 1-7$.

Budiman, A. (2018). EFL techer's Beliefe and Practice on Integrating ICT In The Classroom: A Case Study on The Implementation of SAMR Model In Teaching reading Descriptive Text At MA Assalam Sukoharjo. Jurnal Penelitian Humaniora, 39-51.

Cakiki, D. (2016). The use of ICT in teaching English as a foreign language. Participatory Educational Research (PER), (September 2016).

Chabibie, M. H. (2020). Pendidikan Bermutu : Inovasi Pembelajaran Digital.

Downes, C. (2020). Emergency Remote Teaching using WhatsApp. Jakarta. Retrieved from www.britishcounci.org

Sugiyono, P. D. (2017). Metode penelitian kualitatif. (S. yustiyani Suryandari, Ed.). Bandung: Alfabeta.

Yuliana. (2020). Corona virus diseases (Covid -19); Sebuah tinjauan literatur. Wellness And Healthy Magazine, 2(February), 187-192. 